\title{
Görme Engelliler için Klavye Öğretim Programının Etkililiğinin İncelenmesi
}

\section{Examining Effectiveness of the Keyboard Training Program for the Visually Impaired}

\author{
Mehmet Salih Küçüközyiğit ${ }^{1}$
}

Salih Çakmak ${ }^{2}$

Alıntılama: Küçüközyiğit, M.S., Çakmak, S. (2020). Görme engelliler için klavye öğretim programının etkililiğinin incelenmesi. Ulusal Eğitim Akademisi Dergisi (UEAD), 4(1), 62-88.

Geliş tarihi:

29 Şubat 2020

Kabul tarihi:

24 Nisan 2020

(C) UEAD 2020

Tüm haklarl saklıdır.
Özet: Görme engelli bireylerin eğitimi ve bilgi edinimi için Braille Yazı Sisteminin (BYS) tek başına yeterli olmadığı düşünülmektedir. Görme engelliler için firsat eşitliğini sağlayacak tedbirlerin başında Bilişim tabanlı teknolojiler gelmektedir. Bilişim tabanlı teknolojileri görme engelli bireylerin müfredata erişimine yönelik birçok alternatifi de beraberinde getirmektedir. Görme engelliler için standart klavye ile yazı yazmak erişilebilir, kolay öğrenilen ve ucuz bir yöntem olabilir. Türkçe Etkin Klavye Öğretim Programı (TEKÖP) görme engelli öğrencilerin klavye ile yazma öğrenmelerini amaçlayan bir bilgisayar programdır. Türkçe Etkin Klavye Öğretmen Programı' nın etkililiğini inceleme amacı doğrultusunda "örnek olay çalışması" kullanılmış ve araştırma okuma yazma bilmeyen bir görme engelli öğrenci ile gerçekleştirilmiştir. 53 oturum boyunca bilgisayar rehberliğinde gerçekleşttirilen 15 dakikalık oturumlar halince yapılan öğretimler sonucunda görme engelli öğrencinin seslendirilen metinleri klavye aracıllğı ile yazabildiği gözlemlenmiştir. Öğrenci, öğrenci velisi ve öğretmeninden toplanan sosyal geçerlilik verileri çalışmanın olumlu sonuçlar verdiği yönündedir.

Anahtar kelimeler: Klavye, görme engelli , yazma, yardımcı teknoloji

Abstract: Information-based technologies bring many alternatives for visually impaired individuals to access the curriculum. For the visually impaired, typing with

Received:

29 February 2020

Accepted:

24 April 2020

(C) UEAD 2020

All rights reserved. the standard keyboard can be accessible, easy to learn and inexpensive. Turkish Active Keyboard Teaching Program is a computer program that aims to help students with visual impairments learn to how to write with a keyboard. In order to examine the effectiveness of the Turkish Active Keyboard Teacher Program, a "case study" was used and the research was carried out with an illiterate student. It was observed that the visually impaired student was able to write the voiced texts via the keyboard as a result of the training carried out during the 53 sessions held under computer

${ }^{1}$ (Sorumlu yazar)Arş.Gör.,Gazi Üniversitesi, mskozyigit@gmail.com, https://orcid.org/0000-0001-5980$532 X$.

${ }^{2}$ Doç.Dr., Gazi Üniversitesi, salih_cakmak@gazi.edu.tr, https://orcid.org/0000-0002-9248-0050. 
guidance. Social validity data collected from students, parents, and teachers indicate that the study yields positive results.

Keywords: Keyboard, visually impaired, typing, assistive technology

\section{Giriş}

Okuma yazma becerileri okul hayatında elde edilen ilk ve en önemli becerilerdendir (Giblin, Collins ve Button, 2014). Öğrencilerin akademik alanlarda başarılı olmaları, okuma becerilerini yeterince geliştirmelerine bağlıdır (Milli Eğitim Bakanlığı, 2005). Nitelikli bir okuma yazma eğitiminden yoksun kaldığı için iyi okuyamayan ve doğru olarak anlayamayan öğrencilerin derslerinde başarılı olmaları mümkün görünmemektedir (Washburn, 2016). Modern dünyada, etkin okuma becerisine sahip olmayan bir insan- istenen bilgi birikimine ve bilgi işleme yeteneğine sahip olamaz. Aynı şekilde, etkin bir yazma becerisi olmadığı takdirde, elde edilen bilgi birikimi de çevreyle paylaşılamaz (Bayat ve Çelenk, 2015).

2005-2006 eğitim-öğretim yılında yapılandırmacı yaklaşım benimsenerek hazırlanan Türkçe dersi öğretim programıyla birlikte ses temelli okuma-yazma öğretimi benimsenmiş ve bu yöntem uygulanmaya başlanmıştır (MEB, 2005). Bu yöntemde öğrenciler sırasıyla İlk Okuma Yazmaya Hazırlık Becerileri, İlk Okumaya Başlama ve Bağımsız Okuma Yazma aşamalarını izler (Doğanay-Bilgi ve Güzel-Özmen, 2013; MEB, 2019). İlk okuma yazma çalışmaları; sesi hissetme, tanıma ve ayırt etme, harfi okuma ve yazma, harflerden heceler, hecelerden kelimeler ve kelimelerden cümleler oluşturma aşamalarından oluşturulmuştur (Özcan ve diğerleri, 2013). Bu aşamalardan sonra öğrencilerin bağımsız okuma ve yazmaya başlayabilecekleri varsayılmaktadır (Bayat ve Çelenk, 2015). İlkokula yeni başlayan normal gelişim gösteren çocuklar, bağımsız okuma ve yazma sürecine birkaç ay içerisinde kolayca başlayabilmekte ve çoğunlukla aynı eğitim öğretim yılı içinde dönem sonuna doğru çok yüksek oranlarda bağımsız ve akıcı olarak bu becerileri kullanarak okuyup yazabilmektedirler (Durukan ve Alver, 2008; Yaşar ve Aktay-Güvey, 2015).

Görme engelli öğrenciler ise birincil duyu kanalı olarak dokunmayı ve işitmeyi kullandıklarından okuma yazmayı Braille (kabartma) yazı sistemi (BYS) ile öğrenmektedirler (Koenig, 2000). Braille alfabesi, iki sütunda yer alan altı noktanın çeşitli kombinasyonları ile harfleri, rakamları, noktalama işaretlerini, matematik işaretlerini, müzik notalarını kodlanabildiği bir alfabe sistemidir (MEB, 2015). Fakat BYS'nin Latin harflerle yazmaya göre birtakım 
dezavantajları buluınmaktadır. Latin harfleri ile yazılmış metinler Braille alfabesine dönüştürüldüğünde çok fazla yer kaplamakta ve okuma parmak uçları ile dokunsal olarak yapıldığından okumayı oldukça yavaşlatmaktadır (Erickson ve Hatton, 2007). Okuma yavaşlığını gidermek için ve metinleri kısaltmak gerekir. Bu nedenle BYS'de birtakım kısaltmalar kullanılır. Metinleri kısaltmak için; bir harf kısaltmaları, iki harf kısaltmaları, hece kısaltmaları, kelime kökü kısaltmaları olmak üzere dört farklı kısaltma tekniği kullanılır. Listelenebilecek kısaltmalar toplamda 194 adettir (MEB, 2015). Bu kısaltmaların tamamının öğrenilimesi çok uzun ve yorucu bir süreçtir. BYS’ni öğrenmek zorunda olan görme engelli çocuklar BYS ile belirlenen sesleri, heceleri, kelimeleri ve sonrasında yeralan kısaltmaları okumayı ve yazmayı ilkokul 3.sınıfın sonunda ancak öğrenebilmektedirler (Küçüközyiğit ve Çakmak, 2018). Hatta bir çok total görme engelli öğrencinin ek bir engeli olmamasına rağmen BYS ile okuma yazmayı, kısaltmalar ve noktalama işaretleri ile birlikte ancak 4.sınıfta öğrenebilir. Görme engelli öğrencilerin okuma yazma becerilerini Braille yazı sistemi ile gerçekleştirebilmek için zor ve uzun bir öğrenme sürecinden geçmek zorunda kaldıkları söylenebilir (Küçüközyiğit ve Çakmak, 2018).

BYS’nin olumsuz yönleri sadece kısaltmalar ile sınırlı değildir. Görme engelli öğrenciler BYS ile yazabilmek için birtakım ek materyallere ihtiyaç duymaktadırlar. Yazma esnasında meydana gelen hataları düzeltmek veya yazıyı kontrol etmek ise zordur. BYS ile yazma ve okuma son derece yavaştır (Küçüközyiğit ve Çakmak, 2018). Görme engelli öğrenciler için bir diğer yazma aracı ise Braille Daktilolardır. Fakat Braille daktilolarda da kağıt yerleştirmek, yazılan metni kontrol etmek ve düzeltme yapmak için kağıt daktilonun yazma bölümünden çıkarılıp tekrar yerleştirmeyi gerektirmektedir. Tablet ve çiviye göre kontrol ve düzeltme daha hızlı olsa da süreci yavaşlatmaktadır. Ayrıca Braille daktilolar ithal ve pahalı yardımcı araçlardır.

Görme engellilerin BYS ile yazı yazmayı öğrenmenin zor olması, material kullanım güçlükleri ve erişilebilirlik problemleri fırsat eşitliğine uymayan bir durumu ortaya çıkarmaktadır. Görme engelli bireylerin eğitimi ve bilgi edinimi için yeterli olmadığı da düşünülmektedir (Guerreiro ve diğerleri, 2013). Okuma ve yazmanın diğer akademik becerilerin temeli olduğu düşünüldüğünde görme engelli öğrenciler için sadece eğitim hayatında değil, kişisel gelişim ve mesleki alanlarda da uzun dönemli bir geri kalma etkisinin (Matthew etkisi) kaçınılmaz olduğu belirtilmektedir (Küçüközyiğit ve Çakmak, 2018; Perc, 2014). 
Görme engelliler için fırsat eşitliğini sağlayacak tedbirlerin başında Bilişim Tabanlı Teknolojiler (BTT) gelmektedir. BTT'in başında bilgisayar teknolojileri gelmektedir. Görme engelli bireyler için bilgisayar, farklı programlar yardımıyla dokunsal girdiler (klavye) ve işitsel dönütler sağladıklarından bilgi edinim gereksinimlerini karşılayacak bir araç olarak kullanılabilmektedir (Bouck ve Meyer, 2012; Hink ve Suarez, 2010; Mannheimer, Ferati, Bolchini ve Palakal, 2009; Vener ve Glinert, 1988). Geliştirilen programlar yardımı ile görme engelli ögrenciler bilgisayarı okuma ve yazma aracı olarak kullanabilmekte ve dokunsal olarak bilgisayarı kontrol edebildikleri için kolaylıkla bilgiye erişmeleri mümkün olabilmekte ve yazılı iletişim firsatından da yararlanabilmektedir. Bu sebeple bilgisayar kullanmak görme engelli kullanıcılar için tercihten öte bir gereksinime dönüşmektedir (Angelocci ve Connors, 2002).

Ülkemizde de Dünya' da olduğu gibi görme engelli olan bireylere hizmet edecek şekilde hazırlanmış birçok ekran okuma programı (Jaws, GVZ, Teknoses, Net Okur, Windows-Eyes vb) bulunmaktadır (Subaşığlu, 2000). Bu programlar farklı firmalar tarafından, farklı özelliklerde geliştirilseler de temel olarak bilgisayarda işlenen bilgiyi seslendirme esasına dayanır ve görme engellilerin işitsel algılarını kullanabilmelerini sağlar. Fakat görme engelli öğrencilerin BTT ile tanışmaları akranlarından daha geç olmaktadır. Çünkü görme engelli çocuklar Braille okuma yazmayı öğrendikten sonra bilgisayar derslerini almaya başlamaktadır. Ayrıca görme engelli çocuklar düşünülerek hazırlanan ekran okuma programları (Jaws, GVZ, Teknoses, Net Okur, Windows-Eyes vb.) ülkemizde uygulanmakta olan ses temelli cümle yöntemiyle okuma-yazma öğretim sistematiğiyle uyumlu değildir. Çünkü kullanılmakta olan bütün sesli programlar, sessiz harfleri ses olarak değil harf olarak seslendirmektedir. Örneğin; "l" sesini ekran okuma programları "le", "t" sesini "te", "s" sesini "se" diye seslendirmektedir. Bu şekilde harfler mevcut sesleri ile değil harf olarak sesletildiği için görme engelli çocuklara hizmet eden ekran okuma programları, görme engelli çocuklara okuma, yazma ve dinleme becerilerinin öğretiminde kullanılamamaktadır.

Görme engellilerin bilişim teknolojilerini kullanarak yazmayı öğrenmesine yönelik olarak yapılmış birçok araştırma bulunmaktadır (Avhad, Jadhav, Arbune ve Khainar, 2016; Duarte-Barón, Pabón, Claros ve Gil, 2016; Hong, 2012; Iqbal ve diğerleri, 2014; Jayaprakash, Kanmani, Antony ve Anil, 2016; Khidri, Memon ve Jameel, 2014; Luckner, Bruce ve Ferrell, 2016; Rao, 2006; Wagh ve diğerleri, 2016). Bu araştırmalarda görme engellilerin elle veya BYS ile yazmalarına alternatif olarak kullanılabilecek sistemler üzerinde durulmuştur. Hong (2012) yaptığı araştırmada görme 
engellilerin kulandıkları Braille notalma cihazlarını ve bunların özelliklerini incelemiştir. Araştırma sonucunda Braille notalma cihazlarının internete bağlanma, verileri depolayabilme, kelime işlemciler ile birlikte kullanılabilme, farklı cihazlar ile bağlantı kurabilme, e-posta ve sms gönderme ve farklı cihazları control etme gibi birçok özelliklerinin olduğunu ve görme engelliler için kullanışlı olduğunu ortaya koymuştur. Ayrıca standart klavyelerin de görme engellilerin bilgisayar erişimine imkan sağladığınıda ortaya koymuştur. Goodrich (2003) yaptığı araştırmada görme engellilerin okuma yazmasına yardımcı teknolojileri incelemiş ve bu teknolojileri sayarken standart bilgisayar klavyesinede yer vermis ve görme engellilerin kullanımına uygunluğuna değinmiştir. Benzer bir şekilde Rao (2006) görme engelliler için geliştirilen seslendirme ve Braille cihazlarının kullanılabilirliği ve etkileri üzerine yaptığı araştırmada bu cihazların klavye ile de kullanılabileceğini belirtmiştir. Nicolau, Montague, Guerreiro, Rodrigues ve Hanson (2017) yaptıkları çalışmada ise görme engellilerin standart klavye kullanımları hem labaratuvar ortamında hemde günlük kullanımda değerlendirmiştir. Görme engellilerin klavye kullanımlarının hız, hata oranı ve ortam farklılıklarına göre incelendiği bu kapsamlı çalışmada görme engellilerin sekiz hafta gibi bir sürede ortalama klavye yazma hızına erişebildikleri görülmüştür. Ayrıca görme engellilerin ellerinin klavye üzerindeki hareketleri, hatalarının benzerliği ve hızlanma oranları da incelenmiş ve görme engellilerin bu davranışlarında bellirgin bir örüntü bulunamamıştır.

Klavye ile bir metin oluşturmak, belli tuşların yerlerini görsel olarak belirleyip kinestetik olarak etki ederek bu tuşlara basmayı gerektiren, öğrenilmiş bir beceridir (Freeman, Mackinnon ve Miller, 2005). Öğrenciler klavyede pratik yaptıkça ve yetkinlikleri arttıkça, tuşlara basmak için görsel geri bildirime daha az, kas belleğine daha fazla güvenmeye başlarlar (Marom ve Weintraub, 2015). Motor öğrenme olarak da adlandırılan bu değişimin belli aşamaları vardır (Schmidt, Lee, Winstein, Wulf ve Zelaznik, 2018). Fitts ve Posner (1995) motor öğrenme sürecini bilişsel, çağrışımsal ve özerk gelişimden oluşan üç aşamada incelemişlerdir. Bilişsel aşama, bir görevi tamamlamak için gerekli olan hareket fikrini anlamayı içerir, ancak henüz hareketin nasıl kopyalanayacağı bilinmez (Zwicker ve Harris, 2009). Bu aşamada öğrenci Görsel ve kinestetik geribildirimleri kullanarak klavyeyi daha iyi tanır. Çağrışımsal aşama, motor hareketi üretmek için etkili stratejinin belirlenip, görev performansında ayarlamalar yapmaya başlanma aşamasıdır. Bu aşamada öğrenci tuşlara basmak için hareket kalıplarını içselleştirecek ve görsel uyaranlardan daha çok kinestetik geri bildirime güvenmeye başlayacaktır (Marom ve Weintraub, 2015). Motor 
öğrenmenin son aşaması veya özerk aşama, sadece kinestetik geri beslemeye ile motor becerinin gerçekleştirilmesini içerir (Marom ve Weintraub, 2015; Zwicker ve Harris, 2009). Öğrencilerin yazma hızı ve doğruluğu, pratik ve kas hafizası ile artar (Stevenson ve Just, 2014). Bu seviyede beceri otomatiktir, çok az dikkat verilerek hatta başka görevlerde bulunurken gerçekleştirilebilir (Zwicker ve Harris, 2009).

Öğrenciler klavyede yeterince uzmanlaşmazlarsa tuşları aramak için daha fazla zaman ve metin üretmek için daha az zaman harcayabilirler (Preminger, Weiss ve Weintraub, 2004). Freeman ve diğerleri (2005) öğrenciler için klavyeyle ilgili literatür incelemesinde, beceri kazandıktan sonra klavyeyi uygulama fırsatları sağlamanın yanı sıra, yeterlilik geliştirmede uygun klavye eğitiminin çok önemli olduğu sonucuna varmışlardır.

Klavye ve kelime işlemcilerin kullanımı ile bağlantılı olarak düzenleme kolaylığı, okunabilirlik, daha fazla motivasyon ve artan kelime üretimi miktarı gibi birçok avantajları gözlenmiştir (Freeman ve diğerleri, 2005; Smith, 1989; Stevenson ve Just, 2014). Klavye ile ilgili hatalar meydana gelebildiği, ancak genellikle bu hataların kompozisyonun okunabilirliğini etkilemediği de belirtilmiştir. Klavye hatalarının daha çok boşluk veya yanlış harf kullanımını şeklinde olduğu belirtilmiş̧tir (Smith, 1989). El yazısı ile Braille yazmanın karşılaştırıldı̆̆ında çalışmada ise klavye ile yazmanın öğrencilerin dikkatini daha uzun süre yazma faaliyetinde tutulabildiği ve daha fazla kelime üretmelerine sebep olduğu saptanmıştır (Connelly, Gee ve Walsh, 2007; Hoot, 1986). Klavye ve el yazısını karşılaştıran araştırmalarda ise, el yazısının klevye ile metinleri yazmaya kıyasla daha yorucu bir yöntem olduğu belirlenmiştir (Freeman ve diğerleri, 2005). Benzer bir araştırmada el yazısı ile kopyalama yapan denekler, uzun yazma sürecinde yazdıkları ellerine masaj yapma veya yazmayı durdurarak ellerini rahatlatmaya uğraştıkları görülmüş; klavye ile kopyalama yapan deneklerde ise benzer davranışlar veya herhangi bir yorgunluk belirtisi gözlenmemiştir (Clark, 2014). Klavye ile yazmada, yazılı çalışma üretmek daha az yorulduklarından dikkatlerini el yazısının mekaniğinden ziyade yazdıklarının içeriğine odaklandıkları da saptanmıştır (Berninger, Abbott, Augsburger ve Garcia, 2009; Connelly ve diğerleri, 2007; Freeman ve diğerleri, 2005; Weigelt Marom ve Weintraub, 2015).

Cowles, Hedley ve Robinson (1983) beş -altı yaşındaki öğrencilerin “Touch to Type Typing” programı ile yapılan öğretim sonucunda çok az hata ile yazabildiklerini belirtmişlerdir. Britten (1988) yirmi dakikalık oturumlar halinde haftada üç kez klavye öğretimi gerçekleştirdiği 22 ikinci 
sınıf öğrencisi ile öğretim gerçekleştirilmeyen öğrencilerin klavye yazma becerilerini karşılaştırdığı bir çalışma yapmıştır. Sonuçlar klavye eğitimi alan öğrencilerin klavye ile yazma puanlarında, öğretime katılmayan kontrol grubunun puanlarına göre önemli ölçüde yüksek olduğunu göstermektedir. Bu sonuçlar, Chwirka Chwirka, Gurney ve Burtner (2012) tarafından bir klavye programına katılan 66 ikinci sınıf öğrencisi üzerinde gerçekleştirilen bir pilot çalışma ile de desteklenmektedir. Bu çalışmalar erken yaşta klavye ile yazma becerisinin kazanılmasının mümkün olduğunu göstermektedir. Fakat Pisha (1994) üçüncü sınıftan altıncı sınıflara kadar olan öğrenciler üzerinde yaptıkları araştırmada sınıf seviyesi arttıkça klavye ile yazma becerisinin de arttığ1 gözlemlenmiştir. Nichols (1995) tarafından yapılan bir araştırmada ise üçüncü sınıftan altıncı sınıflara kadar olan öğrencilerin iki klavye öğretim yönteminin karşılaştırılması çalışmasında üçüncü sınıftaki öğrencilerin yeterli klavye ile yazma beceri seviyesine çıkabildikleri üzerinde durulmuştur. Sonuç olarak klavye ile yazma becerisinin öğretilmesi için tavsiye edilen belirli bir yaş bulunmamaktadır.

Klavye eğitimi için öğretimin süresi ile de belirli bir standart yoktur. Daha önceki klavye öğretimi çalışmalarında, 5 saatten 30 saate kadar değişen klavye eğitimi süreleri kullanılmıştır (Freeman ve diğerleri, 2005). Nichols (1995) iki farklı klavye öğretim süresi içren bir araştırma yapmıştır. Klavye öğretimlerinden birisi kısa süreli ve yoğun, diğeri ise uzun süreli ve az çalışma süreleri içeriyordu. Çalışma iki farklı tipteki klavye programını karşılaştırsa da, araştırmacı sonuç olarak olarak uzun süreli ve kısa çalışma oturumları içeren program için daha yüksek klavye hızlarına ulaşıldığını göstermiştir.. Freeman ve diğerleri (2005)toplam yirmibeş ile otuz saatlik eğitimin klavye öğretimi için önerilen bir miktar olduğu sonucuna varmışlardır. Klavye öğretimlerinin gözden geçirilmesi sonucunda bir klavye öğretiminin haftada iki ile beş kez, 20 ila 45 dakikalık öğretimler içermesinin uygun olacağı söylenebilir. Klavye öğretimi ile ilgili yapılacak daha fazla araştırma ile tanı, yaş ve eğitim süreleri ile ilgili daha net bilgilere ulaşılmasına katkı sağlayacaktır.

\section{Türkçe Etkin Klavye Öğretim Programı (TEKÖP)}

Türkçe Etkin Klavye Öğretim Programı (TEKÖP) görme engelli öğrencilerin klavye ile yazma öğrenmelerini amaçlayan bir bilgisayar programdır. TEKÖP'nın oluşturulma süreci özel eğitim alan uzmanlarından görme engelliler için klavye öğretiminde kullanılabilecek strateji ve yöntemleri ile ilgili bilgiler toplanılarak başlanmıştır. Bu bilgiler programın tasarım sürecinde 
kullanılmıştır. Programın kod yazımının devam ettiği süreçte kod yazar ekibi, uygulamacı ve Bilgisayar ve Öğretim Teknolojileri Eğitimi Bölümünden bir alan uzmanı 14 ay boyunca düzenli olarak bir araya gelerek ürün gelişimini takip etmişlerdir. TEKÖP'nın kullanılabilirliği ile ilgili farklı zamanlarda uygulamacı ve kod yazarları beş defa farklı öğrenci ile pilot uygulama gerçekleştirmişlerdir. Bu pilot uygulamalarda programın çalışması ve öğrencilere uygunluğu ile ilgili bilgiler toplanmış ve bu bilgilere göre düzenlemeler gerçekleştirilerek programa son hali verilmiştir. TEKÖP 1. Sınıf öğrencilerin okuma ve yazmayı ses temelli olarak öğrenmeleri ve Türkçe'nin fonetik bir dil olmasından dolayı Türkçe ses temelli olarak hazırlanmıştır.

Evrensel tasarım ölçütlerine göre üretilen standart klavyelerde "F" ve " $J$ " tuşlarında çentikler bulunmaktadır. Bu tuşlara işaret parmakları yerleştirildikten sonra diğer parmaklara

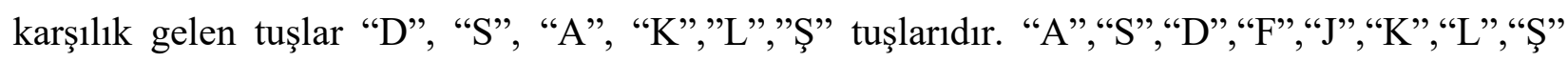
tuşları anasıra tuşlar olarak adlandırılmaktadır. TEKÖP belli bir sıra takip etmektedir. Birinci aşamada öğrencinin anasıra tuşları öğrenmesi amaçlanmaktadır (Tablo 1).

Tablo 1. TEKÖP Aşamaları İ̧̧in Basma Görevi Sayıları ve Harf Grupları

\begin{tabular}{lcccc}
\hline Aşamalar & Harf Grupları & $\begin{array}{c}\text { Istenen } \\
\text { Basma } \\
\text { Görevi }\end{array}$ & $\begin{array}{c}\text { Minimum Doğru } \\
\text { Basılacak Tuş } \\
\text { Sayısı }\end{array}$ & Maksimum Süre \\
\hline 1. Aşama & A,S,D,F,J,K,L,Ş & 40 & 36 & $160 \mathrm{sn}$ \\
2. Aşama & A,S,D,F,J,K,L,Ş & 46 & 41 & $184 \mathrm{sn}$ \\
3. Aşama & E, I, N & 53 & 48 & $212 \mathrm{sn}$ \\
4. Aşama & O,M,U,T,Ü,Y & 61 & 55 & $244 \mathrm{sn}$ \\
5. Aşama & R, I, B & 70 & 63 & $280 \mathrm{sn}$ \\
6. Aşama & Z, Ç, G, C, P & 80 & 72 & $320 \mathrm{sn}$ \\
7. Aşama & H, V, Ğ, F & 93 & 84 & $372 \mathrm{sn}$ \\
8. Aşama & Tüm harfler & 106 & 96 & $424 \mathrm{sn}$ \\
9. Aşama & Tüm Harfler & 122 & 110 & $488 \mathrm{sn}$ \\
\hline
\end{tabular}

$\mathrm{Bu}$ amaca ulaşabilmek için öğrenciye harfin yeri betimlenir, harf seslendirilir, öğrencinin harfe basması istenir, öğrenci harfe bastığında harf tekrar seslendirilir ve öğrenci yumuşak bir uyarı sesi duyar. Öğrencinin farklı harflere bastı̆̆ durumlarda ise sert bir uyarı sesi duyulur. Bu şekilde öğrenci yanlış ve doğru tuşlara bastığında işitsel olarak dönüt alır (Şekil 1). Öğrenci istenen performans düzeyinde doğru bir şekilde ilgili tuşlara basıncaya kadar o aşamayı tekrar eder. Ölçüt sağlanınca bir sonraki aşamaya geçer. Aşamalar Öğrenciler tüm harfleri ve heceleri \%90 doğru bir şekilde ve bir harfi 4 saniye içince basıncaya kadar devam etmektedir. TEKÖP toplam dokuz aşama 
içermektedir ve dokuzuncu aşamanın sonunda öğrencilerin bağımsız olarak klavyede kısa cümleleri bağımsız olarak yazmaları hedeflenmektedir.

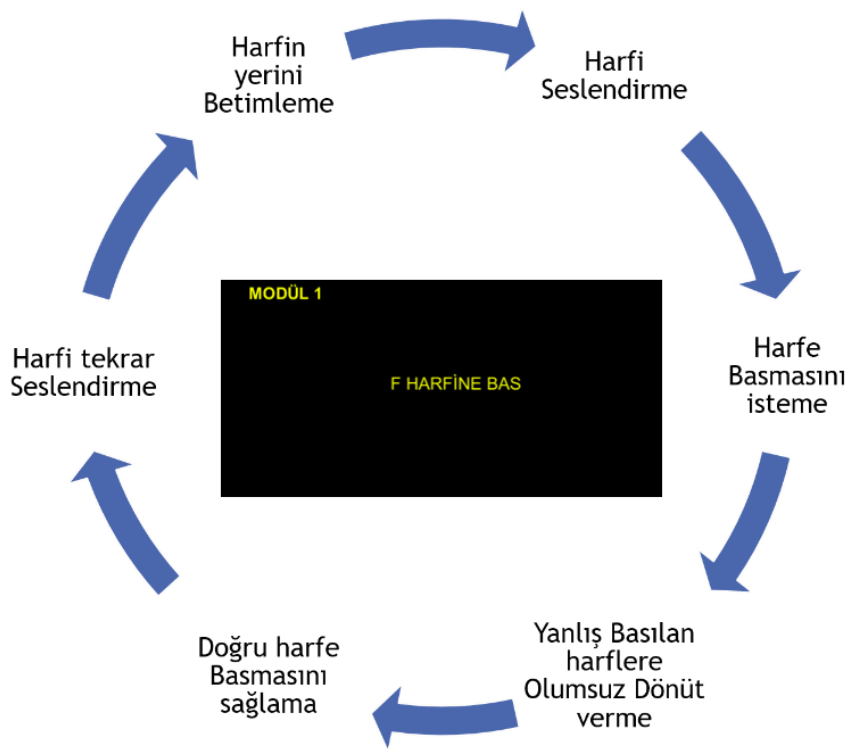

Şekil 1. TEKÖP Çalışma Döngüsü

Harflerin yerlerini öğrencilerin bulması iki amaca hizmet eder. Bunlardan ilki öğrenciye bilgisayar yardımı ile verilen öğretimin olabildiğince iki paydaş arasında olmasını sağlamak. Diğeri ise Öğrencilerin tuşların yerlerini bulmaya çalışır iken klavyeyi daha iyi algıladıkları ve kavradıklarının ön uygulamalarda görülmüş olmasıdır. Öğrencilerin birinci aşama sonunda hece oluşturabilecek kadar harfin sesini ve konumlarını öğrenmeleri ve akıcı bir şekilde ilgili tuşlara basmaları beklenmektedir (Tablo 2). İkinci aşamada basılan tuşlar ayrı ayrı seslendirildikten sonra birleştirilerek hece olarak seslendirilmeye başlanır (Tablo 2). Bu süreç sekizinci aşamaya kadar devam eder. İkinci aşama ve sekizinci aşama arasındaki her aşama için öğrencilere yeni tuşlar ve sesler öğretilir. Önceki aşamalarda öğrendiği sesler ile birlikte yeni öğrendiği seslerden oluşan heceler haf harf yazdırılır ve hece olarak seslendirilir. Her aşama için o aşamada öğrendiği sesler en az üç daha önceki aşamalarda öğrendiği sesler en az bir defa tekrar edilecek şekilde hazırlanmış hece örnekleri arasında rastgele örneklemler alınarak sunulmaktadır. Sekizinci aşamada ise heceler bütün olarak seslendirilir ve öğrenciden bu heceleri çözümleyerek yazmaları beklenir. Son aşamada ise öğrencilere üç ile beş kelimeden oluşan basit cümleler seslendirilerek bu cümleleri yazmaları 
Görme Engelliler için Klavye Öğretim Programının Etkililiğinin İncelenmesi

istenir. Açık erişimli TEKÖP çalıştırma dosyalarına "https://github.com/mskozyigit/tekop" adresinden erişim sağlanabilir. 
Tablo 2. Aşamalara Göre TEKÖP Davranışları

\begin{tabular}{clll}
\hline Aşama & TEKÖP Davranışı & \multicolumn{1}{c}{$\begin{array}{c}\text { Öğrenciden } \\
\text { Beklenen }\end{array}$} & \multicolumn{1}{c}{ TEKÖP Davranışı } \\
\hline 1.Aşama & Harf Seslendirme & Harfe Basma & Basılan Harfleri Seslendirme \\
2.Aşama & Harf Seslendirme & Harflere Basma & $\begin{array}{c}\text { Basılan Harfleri Seslendirme, Heceleri Seslendirme } \\
\text { Basılan Harfleri Seslendirme, Heceleri Seslendirme }\end{array}$ \\
3.Aşama & Harf Seslendirme & Harflere Basma & Basılan Harfleri Seslendirme, Heceleri Seslendirme \\
4.Aşama & Harf Seslendirme & Harflere Basma & Basılan Harfleri Seslendirme, Heceleri Seslendirme \\
5.Aşama & Harf Seslendirme & Harflere Basma & Basılan Harfleri Seslendirme, Heceleri Seslendirme \\
7.Aşama & Harf Seslendirme & Harflere Basma & Basılan Harfleri Seslendirme, Heceleri Seslendirme \\
8.Aşama & Kelime Seslendirme & Kelimeleri Yazma & Basılan Harfleri Seslendirme, Kelimeleri Seslendirme \\
9.Aşama & Cümle Seslendirme & Cümleleri Yazma & Basılan Harfleri Seslendirme, Cümleleri Seslendirme \\
\hline
\end{tabular}

\section{Araştırmanın Amacı}

$\mathrm{Bu}$ araştırmanın genel amacı; görme engelli öğrencilerin akranları ile benzer zamanlarda yazma becerilerini kazanmalarına yardımcı olacağı düşünülen TEKÖP' nın bir öğrencinin yazma becerileri üzerindeki etkilerini gözlemlemektir. Bu genel amaç doğrultusunda aşağıdaki alt sorulara cevap aranacaktır.

1. TEKÖP görme engelli öğrenciye klavyede bulunan ASDFJKLŞ (anasıra) harflerine parmaklarını yerleştirerek dokunsal ve işitsel ayırt etmeye ve konumlarını her seferinde doğru şekilde bularak basmayı öğretmede etkili midir?

2. TEKÖP görme engelli öğrenciye klavye üzerindeki sırasıyla parmaklarını yerleştirdiği ASDFJKLŞ (anasıra) harfleriyle oluşan iki sesli heceleri (KA-LA-SADA vb.) çözümleyerek klavyede doğru bir şekilde yazmasında etkili midir?

3. TEKÖP görme engelli öğrenciye klavye üzerindeki yerleri öğretilen anasıra harfleri ile ELAKİNOMUTÜY harflerinin konumlarını her seferinde doğru şekilde bularak bu sesler ile oluşturulan iki ve üç sesli heceleri dinleyerek, hecelerde bulunan sesleri ayırt edip klavyede doğru bir şekilde yazabilmesinde etkili midir?

4. TEKÖP görme engelli öğrenciye diğer harf gruplarındaki harflerden meydana gelen iki ve üç sesli heceleri dinleyerek, ecelerde bulunan sesleri ayırt edip klavyede doğru bir şekilde yazabilmesinde etkili midir? 
Görme Engelliler için Klavye Öğretim Programının Etkililiğinin İncelenmesi

\section{Yöntem}

TEKÖP'nın etkililiğgini inceleme amacı doğrultusunda, nitel araştırma yöntemlerinden biri olan "örnek olay çalışması” kullanılmıştır. Örnek olay çalışması, tek bir bağlamın içerisindeki dinamikler ve süreçlere odaklanan bir stratejidir ve bilimsel sorulara yanıt aramada kullanılan ayırt edici bir yaklaşımdır (Büyüköztürk, Çakmak, Akgün, Karadeniz ve Demirel, 2010; Miles, Huberman ve Saldana, 2014). Örnek olay çalışması; belirli bir birey, sınıf veya kurumun oluşturduğu bir sistemi/üniteyi anlamak ve bu sistemin/ünitenin üzerinde durmak veya incelemek şeklinde ifade edilmektedir(Karasar, 2009). Bir duruma yönelik unsurlar (ortam, birey, olay, süreç vb. gibi), bütüncül olarak araştırılarak ilgili durumun bu unsurlardan nasıl etkilendiği belirlenmektedir (Yıldırım ve Şimşek, 2003)

\section{Katılımcı}

Araştırmada ölçüt örnekleme tekniği kullanılarak katılımcılar belirlenmiştir. Belirlenen ölçütler; Devlet veya üniversite hastanelerinden total görme engelli tanısı almış olması (bireyin iyi gören gözündeki olağan görme keskinliğinin 20/200 ya da daha az olması ve 20 dereceden daha az görme alanının bulunması. Herhangi bir ek yetersizlik ve gelişimsel gecikmeye sahip olmaması. Sağ ve sol elini gösterebiliyor olması ve parmaklarının isimlerini biliyor olması. Bir yetişkin ile en az 15 dakika etkileşimde kalabilmesi' dir. Katılımcı seçebilmek amacıyla görme engelliler okullarına kurum ziyaretleri yapılmış, okuldan bilgi alındıktan sonra aileler ile görüşülerek araştırma ile ilgili bilgi verilmiş ve gönüllü olan ailelerin çocukları ile doğrudan gözlemler yapılarak öğrencilerin önkoşul becerilere sahip olup olmadıkları kontrol edilerek araştırma katılımcısı seçilmiştir.

$\mathrm{Bu}$ araştırmada katılımcı Milli eğitim bakanlığına bağlı bir görme engelliler okulunda birinci sınıfa devam eden 8 yaşında, görme engelli bir erkek öğrencidir. Katılımcı üniversite hastanesinden veilmiş görme engelli raporuna sahiptir. Katılımcının sağlık kurulu raporu incelendiğinde $\% 3$ görmeye sahip olduğu, retinitis pigmentosa yani tavukkarası teşhisi aldığı görülmektedir. Öğrenci birincil duyu organı olarak dokunma duyusunu kullanmaktadır. Öğrencinin ek bir engeli bulunmamaktadır. Öğrenci bağımsız bir şekilde okul içerisinde sınıfını bulamamakta, okulda hareket edememekte, tenefüs saatlerinde bahçeye çıkamamaktadır. Öğrenci düşük bağımsız hareket becerilerine sahiptir. Öğrenci Braille yazı ve okuma çalışmaları yapmaya henüz yeni başlamış ve Braille okumayı henüz öğrenmemiştir. Öğrencinin ismi etik kurallar gereği gizlenerek 
İlker kod ismi verilmiştir. Öğretmeni İlker'in derslere aktif katılmadığını belirtmiştir. Sınıf ve rehberlik öğretmeni ile yapılan görüşmeler sonucunda Braille okuma ve yazma konusunda zorlandığı ve akranlarının gerisinde kaldığı bilgisine ulaşılmıştır.

\section{Veri Toplama Araçları}

\section{Temel Bilgisayar Becerileri Değerlendirme Formu}

Öğrencinin temel bilgisayar becerilerini değerlendirebilmek için Temel Bilgisayar Becerileri Değerlendirme Formu hazırlanırken TEKÖP'nın yönlendirme tuşları olan TAB, Boşluk ve ENTER tuşları dikkate alınmıştır. Öğrenci sadece bu tuşları kullanarak programı kontrol edebilecekdir. Bu tuşlara göre beceri analizi yapılarak öğrencinin temel bilgisayar becerilerini değerlendirebilmek için Temel Bilgisayar Becerileri Değerlendirme Formu hazırlanmıştır.

\section{El ve Parmak İsimleri Dĕgerlendirme Formu}

TEKÖP'nı yönergelerinde betimlemeler yönlere ve parmak isimlerine göre verilmektedir. Bu sebeple El ve Parmak İsimleri Değerlendirme Formu geliştirilirken temel yön ve parmak isimlerini bilme becerileri listelenmiştir. Bu becerilerin karşısında ise araştırmacının değerlendirme yapması için ise "evet" ve "hayır" sütununa yer verilmiştir.

\section{Pekiştireç Belirleme Formu}

Pekiştireç belirleme formunda öğrencinin ad1-soyad1, yiyecekler-içecekler, oyuncaklar, sosyal ödüller ve etkinlikler başlıkları altında ödül listeleri yer almaktadır. Ödül listelerinin yanındaki üç sütunda ise severim, sevmem, çok severim seçenekleri bulunmaktadır. Formun en alt kısmında ise bu oturum için seçilen pekiştirecin yazılacağı boşluk mevcuttur.

\section{Klavyede Doğru Basılan Harf Sayısı}

öğrenci her bir program aşamasında kendisinden yazması istenen harfler arasından doğru sıra ile doğru bastığı harf sayısıdır. TEKÖP öğrencinin klavye üzerinde doğru bastıkları bütün tuşları otomatik olarak kayıt etmektedir. Bu kayıtlara araştırmacı istediği zaman bilgisayar dökümlerinden ulaşabilir.

Klavyede Yanlış Basılan Harf Sayısı 
Öğrencinin her bir program aşamasında kendisinden yazması istenen harfler arasından yanlış sıra veya yanlış bastığı harf sayısıdır. TEKÖP öğrencinin klavye üzerinde yanlış bastığı bütün tuşları otomatik olarak kayıt etmektedir. Bu kayıtlara araştırmacı istediği zaman bilgisayar dökümlerinden ulaşabilir.

\section{Bir Harfe Basmak Iç̧in Geçen Süre}

Öğrencinin her bir program aşamasını tamamlamak için harcanan dakika cinsinden sürenin, doğru sıra ile doğru bastıkları harflerin sayısına oranıdır. Bir program aşamasını tamamlamak için harcanan sürenin doğru basılan harf sayısına bölünmesi ile bulunur. TEKÖP öğrencinin klavye tuşlarına basarken geçen süreyi otomatik olarak kayıt etmektedir. Bu kayıtlara araştırmacı istediği zaman bilgisayar dökümlerinden ulaşabilir.

\section{Sosyal Geçerlilik Formu}

Araştırmanın sosyal etkilerini gözlemleyebilmek amacı ile bu yönde görüşme soruları araştırmacı tarafından hazırlandıktan sonra, kapsam geçerliliği açısından değerlendirilmesi için uzman görüşüne sunulmuş ve düzenlemeler yapılmıştır. Sosyal geçerlilik formu geliştirilirken dolaylı ve doğrudan etkilenen kişilere yönelik amaç, süreç ve etkiyi ortaya koymaya yönelik sorulara yer verilmiştir. TEKÖP uygulamalarına dair görüşlerini belirlemek için araştırmacı tarafindan Sosyal Geçerlilik Formu bu şekilde geliştirilmiş̧ir. Geliştirilen form yardımı ile uygulama yapılan öğrenci, velisi ve öğretmeninden sosyal geçerlilik verileri toplanırken kullanılmıştır.

\section{Uygulama Güvenirlik Belirleme Formu}

TEKÖP öğretim uygulama basamaklarının araştırmacı tarafından yerine getirilip getirilmediği ve bu basamakların güvenilir bir şekilde uygulanıp uygulanmadığının belirlenmesi amacıyla Uygulama Güvenirliği Belirleme Formu geliştirilmiştir. Uygulama güvenirlik belirleme formu geliştirilirken Araştırmacının uygulaması gereken temel basamaklar listelenmiştir. Beklenen davranışların karşısında ise gözlemcilerin değerlendirme yapmaları için ise "evet" ve "hayır" sütunu bulunmaktadır.

\section{Veri Toplama Süreci}


Very toplama süreci üç bölümden oluşmaktadır. Birinci bölümde öğrenciye TEKÖP’nın kullanımı için temel bilgisayar becerilerinin öğretilmesi ve değerlendirilmesi, ikinci bölüm TEKÖP ile yapılan klavye öğretim oturumları ve son olarak geçerlilik güvenirlik verilerinin toplanmasıdır.

\section{Temel Bilgisayar Becerilerin Öğretilmesi ve Dĕ̆erlendirilmesi}

Uygulamacı, öğrenciye bilgisayarı göstererek tanıtır, çalışmanın adını söyler ve öğrenci için etkili olduğu bilinen bir pekiştirecin verilebileceğini belirterek kuralları açıklar. Öğrencinin bilgisayar klavyesi üzerindeki Boşluk tuşuna basması sağlanarak bunun boşluk tuşu olduğu söylenir. Boşluk tuşunun klavyenin neresinde olduğunu anlaması için eliyle klavyede farklı noktalara dokunması sağlanır. Öğrenciden bunun ne olduğu tekrar sorulur ve boşluk tuşuna basması istenir. Hatalı cevaplar düzeltilir ve doğru tuşa basamadığı durumda fiziksel yardım ile doğru tuşa basması sağlanır ve doğru tepki pekiştirilir. Öğrenci bağımsız olarak doğru tepki verinceye kadar bu şekilde devam edilir.

Daha sonra Öğrencinin bilgisayar klavyesi üzerindeki TAB tuşuna basması sağlanarak bunun TAB tuşu olduğu söylenir. TAB tuşunun klavyenin neresinde olduğunu anlaması için eliyle klavyede farklı noktalara dokunması sağlanır. Öğrenciden bunun ne olduğu tekrar sorulur ve TAB tuşuna basması istenir. Hatalı cevaplar düzeltilir ve doğru tuşa basamadığı durumda fiziksel yardım ile doğru tuşa basması sağlanır ve doğru tepki pekiştirilir. Öğrenci bağımsız olarak doğru tepki verinceye kadar bu şekilde devam edilir.

Daha sonra Öğrencinin bilgisayar klavyesi üzerindeki ENTER tuşuna basması sağlanarak bunun ENTER tuşu olduğu söylenir. ENTER tuşunun klavyenin neresinde olduğunu anlaması için eliyle klavyede farklı noktalara dokunması sağlanır. Öğrenciden bunun ne olduğu tekrar sorulur ve ENTER tuşuna basması istenir. Hatalı cevaplar düzeltilir ve doğru tuşa basamadı̆̆ı durumda fiziksel yardım ile doğru tuşa basması sağlanır ve doğru tepki pekiştirilir. Öğrenci bağımsız olarak doğru tepki verinceye kadar bu şekilde devam edilir. Oturum sonunda öğrenciye seçtiği pekiştireç verilir.

Temel Bilgisayar Becerileri Değerlendirme Formu kullanılarak öğrencinin bu tuşları isimlendirmesi, yerlerini doğru olarak bulabilmesi ve basması değerlendirilir. Öğrenci temel bilgisayar becerilerini $\% 80$ ve üstü düzeylerde kazandığında TEKÖP ile öğretim oturumlarına başlanmiştır. 


\section{Türkçe Etkin Klavye Ö̆gretim Programının (TEKÖP) Öğretim Oturumları}

TEKÖP ile öğretim oturumlarına geçildikten sonra kendisini tekrar eden bir süreç izlenir. TEKÖP açıldıktan sonra öğrenciden başlamak için boşluk tuşuna basmasını ister. Öğrencinin boşluk tuşuna basması ile TEKÖP bir harfi seslendirir ve bu harfe ait tuşun yerini betimler. TEKÖP Öğrenciden bu tuşa basmasını ister. Öğrencinin doğru veya yanlış tepkileri geçen süre ile birlikte TEKÖP tarafından kayıt edilir. Program ilk olarak F harfini seslendirir ve öğrenciden çentikli olan bu tuşa basmasını ister. Sonra J harfini seslendirerek yine çentikli olan bu tuşu bularak basması istenir. Öğrenciden tuşların yerini kendisinin bulması klavye üzerindeki kontrolünü ve algılamasını arttırmak içindir. Öğrencinin TEKÖPnın yönergelerini yerine getirip getirmeme durumlarına göre üç farklı senaryo mevcuttur. a) öğrenci yönergede istenen tuşa bastı b) Öğrenci istenen yönergeyi 5 saniye istenen tuşa basmadı, c) Öğrenci yönerge dışında başka bir tuşa bastı.

Yönergelerde istenen tuşlara bastı̆̆ı durumlarda öğrenciye müdahale edilmez ve TEKÖP çalışmaya devam eder. Öğrenci yönergede istenen tuşa 5 saniye içerisinde basmaz ise öğrenci için sözel ipucundan başlayarak ipuçları giderek arttırılır ve son olarak fiziksel yardım ile istenen tuşa basması sağlanır. Sözel ipucundan başlanmasının sebebi Öğrencinin klavyeyi dokunsal olarak algılamasını kesmemek ve öğrencinin tekrar parmaklarını yerleştirmesi için zaman kaybetmesini engellemektir. Öğrencinin istenen tuş dışındaki diğer tuşlara bastığı durumlarda programdan olumsuz dönüt verilir ve araştırmacı tarafından artan ipuçları verilerek doğru tuşu bulması sağlanır.

Öğrenci herbir oturum için TEKÖP tarafından belirlenmiş olan belli sayıda tuşa $\% 90$ oranında doğru olarak ve ortalama bir tuşa 4 saniye içerisinde bastığı zaman bir sonraki aşamaya geçer. Herbir oturum için öğrenciden istenen tuşlara basması bir beceri, bu tuşlara 4 saniye içerisinde basması ise akıcılık olarak ele alınmıştır. Eğer öğrenci herbir aşama için talep edilen basmaların \%90' dan az tuşa doğru tuşa basar veya birt tuşa basmak için ortalama 4 saniyeden daha uzun bir zaman geçerse aynı aşamayı tekrar eder. Doğru basılan harf sayısı, yanlış basılan harf sayısı, bir tuşa basmak için geçen ortalama süre bilgileri TEKÖP tarafından kayıt edilir. TEKÖP uygulama oturumları haftada 4 gün ve hergün 15 dakika olarak planlanmıştır.

\section{Geçerlilik ve Güvenirlike Verilerinin toplanması}

TEKÖP oturumları sona erdikten sonra geçerlilik ve güvenirlik verileri toplanmaya başlanmıştır. TEKÖP öğretim oturumları videolarının \%40’ı seçkisiz atama ile seçilerek seçilen 
videolar Özel Eğitim Bölümü Görme Engellilerin Eğitimi Anabilim Dalı'nda araştırma görevlisi olarak çalışan aynı zamanda doktora eğitimine devam eden iki kişi tarafından izlenmiştir (Tablo 4). Gözlemciler videoları izlerken uygulama güvenirlik formlarını doldurmuşlar ve bu bilgiler kayıt altına alınmıştır.

Sosyal geçerlilik verileri ise öğrenci, öğrenci ebeveyni ve öğretmeni ile sosyal geçerlilik verilerinin toplanması için görüşmeler düzenlenerek toplanmıştır.. Sosyal geçerlilik verileri bu görüşmelerde Sosyal Geçerlilik Formu kullanılarak toplanmıştır.

\section{Veri Analizi}

Temel bilgisayar becerilerinin değerlendirilmesi yüzde olarak hesaplanmıştır. Öğrenci \%80 veya daha yüksek bir oranda temel bilgisayar becerilerine sahipse temel bilgisayar becerilerilerine sahip olarak değerlendirilmiştir.

TEKÖP 'nın herbir aşaması için belli sayıda harf tuşuna basma görevi öğrenciden beklenmektedir (Tablo 1). Bu görevleri gerçekleştirirken öğrenci hem bir harfe basmak için geçen ortalama süre üzerinden hem de klavyede doğru basılan harf sayısı bakımından değerlendirilmiştir. Öğrenci o an bulunduğu aşamada bir harfe basmak için ortalama olarak 4 saniyeden daha uzun süre geçirdiyse o aşama için başarısız olmuş demektir. Aynı şekilde öğrenci o an bulunduğu aşamada toplam basma görevlerinin \%90 nından az doğru harfe bastırya yine o aşama için başarısız olmuş demektir. Öğrenci her iki şartı bir arada sağladığı zaman o aşama için başarılı olmuş demektir ve bir sonraki aşamaya geçebilir. Bütün aşamaların analizleri bu şekilde yapılmaktadır. Ayrıca klavyede doğru basılan harflerin standart sapması alınarak öğrencinin doğru basma sayılarının farklılaşması da analiz edilmiştir. Amaca Yönelik, Sürece Yönelik, Etkiye Yönelik olarak hazırlanan Sosyal Geçerlilik Formu sonuçları betimsel olarak değerlendirilmiştir. Öğrencinin, ebeveynlerin ve öğretmenlerin sosyal geçerlilik verileri bu değerlendirmeye dâhil edilmiştir.

\section{Etik Konular}

$\mathrm{Bu}$ araştırma başlamadan önce katılımcı öğrencinin velisi gönüllü onam formunu imzalamış ve katılımcı öğrencinin kendisi de çalışmaya gönüllü olmuştur.

Araştırmada yararlanılan kaynaklar telif hakları düzenlemelerine riayet dilerek kullanılmıştır. 
Araştırma Ankara İl Milli Eğitim Müdürlüğü, 24.10.2019 tarihli, 14588481-605.99E.1923875 sayı no ile araştırma izinleri alınarak yapılmıştır.

\section{Bulgular}

Temel bilgisayar becerilerinin öğretimi oturumlarından sonra TEKÖP öğretim oturumlarına geçilmiştir. Öğretim oturumlarının başlamasıyla birlikte İlker'in klavyede doğru bastığı kelime sayısı artmaya, yanlış bastığı tuş sayısı ve bir harfe basmak için geçen süre azalmaya başlamıştır (Tablo 3).

İlker 12 TEKÖP oturumu sonucunda klavyede doğru basılan harf sayısını kararlı bir şekilde \%90 ve üstü değerlere taşımış ve birinci aşamayı tamamlamıştır. İkinci aşamayı 8 oturum, üçüncü aşamayı 7 oturum, dördüncü aşamayı 5 oturum, beşinci aşamayı 6 oturum, altıncı aşamayı 6 oturum, yedinci aşamayı 6 oturum, sekizinci aşamayı 3 oturum, dokuzuncu aşamayı 3 oturum sonucunda tamamlamıştır (Tablo 3).

İki, dört ve sekiz hafta sonra gerçekleştirilen izleme oturumları için İlker'in ortalama klavyede doğru basılan harf sayısı 110, ortalama klavyede yanlış basılan harf sayısı 11,3, bir harfe basmak için ortalama geçen süre 3 saniye, doğru bastığı tuşların standart sapması 5,1 harf olmuştur. İlker'in izleme oturumlarında ortalama doğruluk oranı $\% 90$ olmuştur.

Tablo 3. Görme Engelli Öğrencinin TEKÖP Aşama Sonuçları

\begin{tabular}{lllll}
\hline Aşamalar & Oturum Sayısı & $\begin{array}{l}\text { Ort. Doğru } \\
\text { Basılan Harf } \\
\text { Sayısı }\end{array}$ & $\begin{array}{l}\text { Ort. Tuşa } \\
\text { Basma Süresi }\end{array}$ & $\begin{array}{l}\text { Ort. } \\
\text { Doğruluk \% }\end{array}$ \\
\hline 1.Aşama & 12 & 24 & 5,6 & $\% 58$ \\
2.Aşama & 8 & 39 & 3,8 & $\% 86$ \\
3.Aşama & 7 & 46 & 3,8 & $\% 88$ \\
4. Aşama & 5 & 53 & 3,4 & $\% 86$ \\
5.Aşama & 6 & 61 & 3,4 & $\% 87$ \\
6.Aşama & 6 & 71 & 2,9 & $\% 88$ \\
7.Aşama & 3 & 82 & 2,8 & $\% 88$ \\
8.Aşama & 3 & 98 & 2,2 & $\% 93$ \\
9.Aşama & 3 & 112 & 3 & $\%$ \\
\hline
\end{tabular}

Araştırma Alt Amaçlarına Yönelik Bulgular 
1. Görme engelli öğrenci için Türkçe Etkin Klavye Öğretim Programı klavye üzerindeki " $F, J, A, S, D, K, L, S\}$ ” harflerini dokunsal ve işitsel olarak ayırt etmelerinde ve konumların her seferinde doğru olarak bulup parmaklarını konumlandırmasında etkili midir?

İlker birinci aşamayı 12 oturumda $\% 90$ ve üzeri bir başarı göstererek ve bir harfe basmak için ortalama geçen süre 3,9 olarak tamamlamıştır İlkerin birinci aşamayı tamamlaması yaklaşık olarak bir ay sürmüştür. İlkerin birinci aşamayı bu kadar uzun sürede tamamlamasının sebebinin ilk defa bilgisayar ile doğrudan etkileşime geçerek bireysel olarak çalışması olduğu düşünülmektedir. Birinci aşama "F,J,A,S,D,K,L,Ş" harflerinin dokunsal olarak klavye üzerindeki yerleri ve bu harflerin seslerinin eşleştirilme becerilerini gerektiren görevlerinden oluştuğu göz önüne alındığında görme engelli öğrencinin Fonetik Temelli Yazma ve Seslendirme Yazılımı ile yapılan öğretim sonucunda "F,J,A,S,D,K,L,Ş" harflerini dokunsan ve işitsel olarak ayırt etmesinde ve konumlarını her seferinde doğru olarak bulup parmakları ile doğru şekilde basmasında etkili olduğu söylenebilir.

2. $\quad$ Görme engelli öğrenci için Türkçe Etkin Klavye Öğretim Programı kullanarak kendisine söylenen " $F, J, A, S, D, K, L, S\}$ " harflerinden meydana gelen iki sesli heceleri (KA-LA-SA$D A$ vb.) çözümleyerek heceleri klavyede doğru bir şekilde yazmasında etkili midir?

İlker ikinci aşamayı 8 oturum sonucunda klavyede doğru basılan harf sayısını kararlı bir şekilde $\% 90$ ve üstü değerlere taşımış, bir harfe basmak için ortalama geçen süreyi 3,4'e taşımış ve tamamlamıştır. İkinci aşamayın görme engelli Öğrencinin "F,J,A,S,D,K,L,Ş” harflerinden meydana gelen iki sesli heceleri (KA-LA-SA-DA vb.) çözümleyerek heceleri klavyede doğru bir şekilde yazma becerilerini gerektiren görevlerden oluştuğu göz önüne alındığında görme engelli öğrencinin Fonetik Temelli Yazma ve Seslendirme Yazılımı ile yapılan öğretim sonucunda "F,J,A,S,D,K,L,Ş" harflerinden meydana gelen iki sesli heceleri (KA-LA-SA-DA vb.) çözümleyerek harfleri klavyede doğru bir şekilde yazmasında etkili olduğu söylenebilir.

3. $\quad$ Görme engelli öğrenci için Türkçe Etkin Klavye Öğretim Programı söylenen

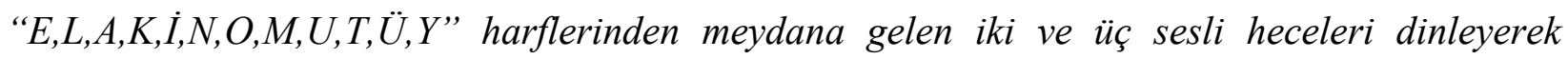
hecelerde bulunan sesleri ayırt edip yazabilmesinde etkili midir?

İlker üçüncü aşamayı 7 oturum, dördüncü aşamayı 5 oturum sonucunda klavyede doğru basılan harf sayısını kararlı bir şekilde \%90 ve üstü değerlere taşımış ve tamamlamıştır. Üçüncü 
aşama öğrencinin "E,L,A,K,İ,N" harflerinden meydana gelen iki sesli heceleri (Kİ-EL-AS-KAL vb.) çözümleyerek heceleri klavyede doğru bir şekilde yazma becerisini gerektiren görevlerden oluşmaktadır. Dördüncü aşama ise öğrencinin "O,M,U,T,Ü,Y" harflerinden meydana gelen iki sesli heceleri (MU-TÜY-SU-YO vb.) çözümleyerek heceleri klavyede doğru bir şekilde yazma becerisini gerektiren görevlerden oluşmaktadır. Bunlar göz önüne alınarak TEKÖP ile yapılan öğretimin "E,L,A,K,İN,O,M,U,T,Ü,Y" harflerinden meydana gelen iki ve üç sesli heceleri dinleyerek hecelerde bulunan sesleri ayırt edip yazabilmesinde etkili olduğu söylenebilir.

4. $\quad$ Görme engelli ögrrenci için Türkçe Etkin Klavye Öğretim Programı diğer harf gruplarındaki harflerden meydana gelen iki ve üç sesli heceleri dinleyerek hecelerde bulunan sesleri ayırt edip yazabilmesinde etkili midir?

Sekizinci aşamada tüm harf gruplarını içeren kelimelerin çözümlenerek yazılmasını gerektiren görevlerden meydana gelmektedir. İlker sekizinci aşamayı başarılı bir şekilde tamamlayabilmiştir. Dokuzuncu aşamada ise 4 ile 5 arasında kelime içeren cümlelerin çözümlenerek yazılmasını gerektiren görevlerden meydana gelmektedir. Bunlar göz önünde bulundurulduğunda görme engelli öğrencinin TEKÖP ile diğer harf gruplarındaki harflerden meydana gelen iki ve üç sesli heceleri dinleyerek hecelerde bulunan sesleri ayırt edip yazabilmesinde etkili olduğu söylenebilir.

\section{Güvenirlik Bulguları}

Gözlemciler güvenirlik formlarını doldurulduktan sonra veriler; Gözlenen araştırmacı davranışı/ Planlanan araştırmacı davranışı x100 formülü kullanılarak hesaplanmıştır. Araştırmanın uygulama güvenirlik değeri 3034/3185*100 = \%95 olarak hesaplanmıştır (Tablo 4).

Tablo 4. Güvenirlik Maddeleri ve Puanlart

\begin{tabular}{lc}
\hline \multicolumn{1}{c}{ Planlanan Araştırmacı Davranışları } & Gözlenen/Planlanan \\
\hline Etkinlik sonu için öğrenciyle birlikte uygun pekiştirecin seçilmesi. & $52 / 53$ \\
Öğrenciye çalışma sırasında uyması gereken kuralların açıklanması. & $53 / 53$ \\
Bilgisayar klavyesinin öğrencinin rahatlıkla parmaklarını konumlandırabileceği bir şekilde & $51 / 53$ \\
önüne yerleştirmesi. & \\
TEKÖP'ün çalıştııılmasıı. & $53 / 53$ \\
\hline
\end{tabular}


Öğrencinin yönergede istenen tuşa basması için 4 saniye beklenmesi.

Öğrencinin uygun tuşa bastığg durumda tepkisiz kalması.

Öğrencinin uygun tuşa 4 saniyede basmadığı durumda sesin tekrar edilmesi. yerinin betimlemesi.

Sözel ipucuna rağmen öğrencinin tuşun yerini bulamadığı durumda fiziksel yardım ile tuşa

$65 / 70$ basmasının sağlanması.

Etkinlik sonunda öğrenci pekiştirecin verilmesi.

\section{Sosyal Geçerlilik Bulguları}

Araştırma sona erdikten sonra sosyal geçerlilik formları araştırmaya katılan öğrenciye, öğrenci velisine ve öğrencinin öğretmeni ile uygulanmıştır. Sosyal geçerlilik formu 10 soru içermektedir.

1. (Çocuğunuzun/Öğrencinizin) Bilgisayarda yazı yazmayı öğrenmeyi ister miydin?

İlker "ben bilgisayarı hiç bilmiyordum, ama öğrenmek istiyordum" şeklinde cevap vermişlerdir. Annnesi "İlker henüz okuma yazma bilmediği için biz bilgisayar falan hiç düşünmemiştik" demiştir. Öğretmeni ise "Benim aklıma geliyordu ama şuan erken olduğunu düşünüyordum" demiştir.

2. (Çocuğunuzun/Öğrencinizin) Bilgisayarda yazı yazmayı öğrendiğinde bunun sana başka faydalar da sağlayacağını düşünüyor musun?

İlker bu soruya "evet bence" şeklinde cevap vermis. Annesi "bizim bilgisayarımız yok, o yüzden çok fayda sağlayacağını düşünmüyorum" demiştir. Öğretmeni ise bilgisayarda yazı yazmalarının öğrenci için başka faydalar da sağlamasının muhtemel olduğunu belirtmiştir.

3. (Çocuğunuzun/Öğrencinizin) Çalış1lan bu becerinin, senin öğrenmen gereken diğer beceriler arasından öncelikli beceri olduğunu düşünüyor musun? 
İlker bu soruya "bilmiyorum" şeklinde cevap vermis. Annesi klavye ile yazmadan daha önemli becerilerin olduğunu düşündüğünü belirtmiştir. Öğretmeni öğrencinin daha önemli akademik becerilerde eksiklikleri olduğunu söylemiş̧tir.

4. (Çocuğunuzun/Öğrencinizin) Sence bilgisayarda yazı yazmayı öğrenmen senin diğer akademik becerilerine olumlu bir etki yapabilir mi?

İlker bu soruya "olabilir tabi" şeklinde cevap vermis. Annesi "bilgisayar ile her şeyi daha kolay öğrenir herhalde” şeklinde olumlu görüş̧ bildirmiştir. Öğretmeni de bilgisayarda yazı yazmayı öğrenmesinin onun diğer akademik becerilerine katkı sağlayacağını belirtmiştir.

5. (Çocuğunuzun/Öğrencinizin) Bilgisayarda yazı yazmayı öğrenirken bilgisayarın sana rehberlik etmesi hoşuna gitti mi?

İlker "bilgisayarın böyle olduğunu bilmiyordum, çok güzel oldu" derken Annesi "tabi ki, bilgisayarla çok iyi anlaşıyorlar, bizde de anlatıyordu. keşke bizi de böyle dinleseler" demiştir. Öğretmeni ise öğrencinin bilgisayarda yazı yazmayı öğrenmesi sürecinde bilgisayar rehberliğinden hoşnut olduğunu iletmiştir.

6. (Çocuğunuzun/Öğrencinizin) $\mathrm{Bu}$ çalışma sırasında hoşuna gitmeyen bir durum ile karşılaşıtın mı?

İlker çalışmanın çok uzun sürdüğünü ve sürekli aynı modülü tekrar ettiğinden şikayet etmiştir. Annesi ve öğretmeni ise bu süreçte herhangi olumsuzluk ile karşılamadıklarını belirtmişlerdir.

7. (Çocuğunuzun/Öğrencinizin) Bu çalışma sayesinde bilgisayarda yazı yazma becerinin geliştiğini düşünüyor musun?

İlker bilgisayarda yazı yazma becerilerinin geliştiğini söylemiştir. Annesi ve Öğretmeni de İlker'in bilgisayarda bağımsız olarak yazı yazacak kadar geliştiğini belirtmişlerdir.

8. (Çocuğunuzun/Öğrencinizin) $\mathrm{Bu}$ çalışmanın senin ses ve harf bilgini geliştiğini düşünüyor musunuz?

İlker ses ve harf bilgisinin geliştiğini düşündüğünü söylemiştir. Annesi ve öğretmeni de öğrencinin ses ve harf bilgisi olarak geliştiğini düşündüğünü söylemiştir 
9. (Çocuğunuzun/Öğrencinizin) Bilgisayarda yazı yazmayı öğrenmede bilgisayarın sana rehberlik etmesinin etkili olduğunu düşünüyor musun?

İlker bilgisayar rehberliğinden memnun olduğunu ifade etmiştir. Süreci "bilgisayar ne güzel ne yapacağını söylüyor o zaman çok kolay oluyor” şeklinde tanımlamıştır. Annesi bilgisayarın rehberliğinin öğrenci tarafından takip edildiğini ve etkili olduğunu belirtmiştir. Öğretmeni de bilgisayar rehberliğinin etkili olduğunu belirtmiştir.

10. (Çocuğunuzun/Öğrencinizin) Sence diğer arkadaşların da bilgisayarda yazı yazmak bu şekilde öğrenebilir mi?

İlker "bazıları öğrenebilir ama bazıları da öğrenemez" diyerek çekinceleri olduğunu söylemiştir. Annesi diğer arkadaşlarına da bu şekilde klavye ile yazma becerisinin öğretilebileceğini belirtmiştir. Öğretmeni is ek bir engel durumu olmakdığı durumlarda İlker'in diğer arkadaşlarına da bu şekilde klavyede yazma öğretilebileceğini söylemiştir.

Öğrenciye/ Veliye/ Öğretmene bu sorular dışında bu çalışma ile ilgili eklemek istedikleri bir düşünceleri olup olmadığı sorulduğunda ise İlker "Ben artık klavye ile yazmayı öğrendim, bilgisayarda başka şeyler de yapmayı öğretecek misiniz?" demiş. Annesi "ben bu kadarını beklemiyordum hocam. Çok sağ olun" demiştir. Öğretmeni ise "İlker çok yavaş bir öğrenci olmasına rağmen klavye kullanmayı bu şekilde öğrenmesi beni çok şaşırttı. Sesleri ve harfleri de bu çalışma sayesinde kolay öğrendiğini düşünüyorum. Bilgisayar kullanmayı da kısa zamanda öğrenirse kendisi için çok faydalı olur.” demiştir.

\section{Sonuç ve Öneriler}

Araştırma sonucunda görme engelli öğrenciye klavye ile yazma becerilerinin öğretilmesinde TEKÖP’nın etkiliğine yönelik olarak sorulan dört farklı araştırma sorusu bulunmaktadır. Bu sorulara araştırmanın sonuçlarına dayalı olarak olumlu sonuçlar alınmıştır. Görme engelli öğrenci klavyede bulunan çentikli harf tuşları ve harf seslerini eşleştirebilmiş, sonrasında diğer harf gruplarında bulunan harf tuşları ve seslerini de eşleştirebilmiş, bu harflerin yerlerini klavye üzerinde her seferinde doğru şekilde bulmuş, iki sesli, üç sesli hece ve kelimeleri klavye ile yüksek doğruluk oranlarında ve hızlı bir şekilde yazabilecek hale gelmiştir. Ayrıca araştırma sonunda sosyal geçerlilik bulugları incelendiğinde öğrenci ve velilerin bilgisayar ile klavyede yazma becerisinin çğretilmesini öncelikli olarak tanımlamasalar da bilgisayae 
rehberliğinden memnun oldukları görülmüş ve öğrencinin beceriyi başarılı bir şekilde gerçekleştirdiğini belirtmişlerdir.

Alanyazında yazma güçlüğü çeken, gelişimsel geriliği ve dikkat dağınıklığı olan, el yazısı yazma ile ilgili becerilerde zorlanan çocuklar için bir araç olarak kullanılan klavye ile yazmanın görme engelli çocuklar içinde alternatif bir yazma aracı olarak kullanılabileceğine yönelik bulgulara ulaşılmıştır. Bunun yanında görme engelli öğrencilerin okuma yazma öğrenme süreçlerinin zorluğu da ele alındığında TEKÖP veya buna benzer klavye öğretim programları ile klavyede yazma öğrenmenin görme engelli öğrenciler için de kullanışlı olduğu söylenebilir. Fakat görme engelliler ile ilgili teknoloji içeren araştırmalar ve uygulamaların tarihi uzun yıllar öncesine dayanmasına rağmen, klavye ile yazma öğretimi ve görme engellilerde klavye ile yazma hızı ile ilgili herhangi bir çalışmaya rastlanmamıştır.

$\mathrm{Bu}$ araştırmada görme engelli bir öğrencinin bir bilgisayar programı aracılığı ile klavyede yazma becerisi kazanması ele alınmıştır. İleride yapılacak olan araştırmalar bilgisayar programı ile klavyede yazma becerisinin öğretiminin etkisini gösterecek farklı araştırma yöntemleri ile ortaya koyabilir. Farklı araştırmacılar tarafından daha yüksek katılımcı sayısı ile farklı yöntemler ile yapılacak araştırmalar görme engelli öğrencilere klavyede yazma öğretiminde bilgisayar programlarının kullanılmasının etkili bir öğretim yöntemi olduğunu ortaya koymak için önemlidir. Ayrıca farklı bilgisayar programlarının görme engelli öğrencilerin klavyede yazmayı öğrenmelerindeki etkileri üzerine de araştırmalar yapılabilir.

Etik Kurul İzin Bilgisi: Bu kısımda Bu araştırma, MEB Yenilik ve Eğitim Teknolojileri Genel Müdürlüğ̈̈nün 24/10/2019 tarihli 14588481-605.99-E.1923875. sayılı karart ile alınan izinle yürütülmüş̧ür.

\section{Yazar Katkı Beyanı:}

1. Mehmet Salih Küçüközyiğit: Kavramsallaştırma, öğretim materyali tasarlama, öğretim materyali geliştirme, ölçme aracı geliştirme, deneysel uygulama, veri toplama, veri analizi, yazım ve düzenleme.

2. Salih Çakmak: Danışmanlık (metedoloji, öğretim materyali geliştirme, ölçme aracı geliştirme, veri analizi), inceleme ve düzenleme. 


\section{Kaynakça}

Angelocci, R. M., \& Connors, B. G. (2002). Assessing writing software tools for people with vision impairment, learning disability, and/or low literacy. New Orleans, USA: AFB

Avhad, A., Jadhav, R., Arbune, A., \& Khainar, K. (2016). E-braille - a self learning braille. International Journal of Infinite Innovations in Technology, 4(3).

Bayat, S., \& Çelenk, S. (2015). İlköğretim birinci sınıf öğrencilerinin okuma yazma becerileri başarı düzeylerinin belirlenmesi. Illkögretim Online, 14(1).

Berninger, V. W., Abbott, R. D., Augsburger, A., \& Garcia, N. (2009). Comparison of pen and keyboard transcription modes in children with and without learning disabilities. Learning Disability Quarterly, 32(3), 123-141. doi:10.2307/27740364

Bouck, E. C., \& Meyer, N. K. (2012). eText, Mathematics, and students with visual impairments: What teachers need to know. Teaching Exceptional Children, 45(2), 42-49.

Britten, R. M. (1988). The effects of instruction on keyboarding skills in grade 2. Educational Technology, 28(4), 34-37.

Büyüköztürk, Ş., Çakmak, E. K., Akgün, Ö., Karadeniz, Ş., \& Demirel, F. (2010). Scientific research methods. Ankara: Pegem Akademi.

Chwirka, Gurney, \& Burtner. (2012). Keyboarding and visual-motor skills in elementary students: A pilot study. Occupational Therapy in Health Care, 16(2).

Clark. (2014). The importance of Braille in the 21st century. Journal of South Pacific Educators in Vision Impairment, 7(1), 24-30.

Connelly, V., Gee, D., \& Walsh, E. (2007). A comparison of keyboarded and handwritten compositions and the relationship with transcription speed. British Journal of Educational Psychology, 77(2), 479-492. doi:10.1348/000709906X116768

Cowles, M., Hedley, M., \& Robinson, M. (1983). An analysis of young children learning keyboarding skills. ERİC. (ED238542).

Doğanay-Bilgi, A., \& Güzel-Özmen, R. (2013). Okuma öğretimi. H. İ. Diken (Ed.), İlköğretimde Kaynaştırma. Ankara: Pegem Akademi.

Duarte-Barón, K., Pabón, J. X., Claros, R., \& Gil, J. J. (2016). Design and construction of a device for facilitating the learning of Braille literacy system. Ingeniería y competitividad, 18(1), 79-92.

Durukan, E., \& Alver, M. (2008). Ses temelli cümle yönteminin öğretmen görüşlerine göre değerlendirilmesi. The Journal of International Social Research, 1(5).

Erickson, K. A., \& Hatton, D. (2007). Literacy and visual impairment. Semin Speech Lang, 28(1), 58-68. doi:10.1055/s-2007-967930

Fitts, P., \& Posner, M. (1995). Motor control: theory and practical application. Baltimore: Williams \& Wilkins.

Freeman, A. R., Mackinnon, J. R., \& Miller, L. T. (2005). Keyboarding for students with handwriting problems: A literature review. Physical \& Occupational Therapy In Pediatrics, 25(1-2), 119-147. doi:10.1080/J006v25n01_08

Giblin, S., Collins, D., \& Button, C. (2014). Physical literacy: importance, assessment and future directions. Sports Medicine, 44(9), 1177-1184. doi:10.1007/s40279-014-0205-7

Goodrich, G. L. (2003). Available and emerging technologies for people with visual impairment. Aging and The Sense, 27(1). 
Guerreiro, J., Gonçalves, D., Marques, D., Guerreiro, T., Nicolau, H., \& Montague, K. (2013). The today and tomorrow of Braille learning. 15th International ACM SIGACCESS Conference on Computers and Accessibility, Washington.

Hink, R. B., \& Suarez, A. A. (2010). Basic human computer interface for the blind. 8th Latin American and Caribbean Conference for Engineering and Technology, Peru.

Hong. (2012). An alternative option to dedicated braille notetakers for people with visual impairments: Universal technology for better access. Journal of Visual Impairment \& Blindness, 2016(10), 650-665. doi:Doi 10.1177/0145482x1210601009

Hoot, J. L. (1986). Keyboarding instruction in the early grades: Must or mistake? Childhood Education, 63(2), 95-101. doi:10.1080/00094056.1986.10521749

Iqbal, M. M., Balaji, L. P., Jayakar, M., Gokul, P., Kumar, R. K., \& Jairam, R. (2014). Virtual simulation and embedded module of mobile phone using modified Braille display. Devices, Circuits and Systems (ICDCS).

Jayaprakash, M., Kanmani, K., Antony, P., \& Anil, B. (2016). Braille writer cum translator with echo: A novel approach. N. R. Shetty, P. N. Hamsavath, \& N. Nalini (Eds.), Emerging research in computing, information, communication and applications (pp. 103-116). İndia: Springer.

Karasar, N. (2009). Bilimsel araştırma yöntemi: Kavramlar, ilkeler, teknikler. Ankara: Nobel Yayın Dağitim.

Khidri, S. A., Memon, S. H., \& Jameel, A. (2014). Blind aid: A self-learning braille system for visually impaired. International Journal of Engineering Research and General Science, 2(4), 641-647.

Koenig, A. J. (2000). Foundations of education: Instructional strategies for teaching children and youths with visual impairments (Vol. 2). America: American Foundation for the Blind.

Küçüközyiğit, M. S., \& Çakmak, S. (2018). 4. Sinıfa devam eden görme engelli öğrencilerin braille okuma seviyelerinin belirlenmesi. X. Uluslararası Eğitim Araştırmaları Kongresi, Nevşehir.

Luckner, J. L., Bruce, S. M., \& Ferrell, K. A. (2016). A summary of the communication and literacy evidence-based practices for students who are deaf or hard of hearing, visually impaired, and deafblind. Communication Disorders Quarterly, 37(4), 225-241. doi:10.1177/1525740115597507

Mannheimer, S., Ferati, M., Bolchini, D., \& Palakal, M. (2009). Educational sound symbols for the visually impaired. Universal Access in Human-Computer Interaction, 56(14), 106-115.

Marom, H. W., \& Weintraub, N. (2015). The effect of a touch-typing program on keyboarding skills of higher education students with and without learning disabilities. Research in developmental disabilities, 47, 208-217.

MEB. (2005). Türkçe dersi öğretim programı. Ankara: Milli Eğitim Bakanlığı

MEB. (2015). Görme engellilere okuma yazma öğretim kılavuzu. Ankara: Özel Eğitim ve Rehberlik Hizmetleri Genel Müdürlüğ̈̈

MEB. (2019). Türkçe dersi ögrretim programı (İlkokul ve ortaokul 1, 2, 3, 4, 5, 6, 7 ve 8. Sinıflar). Ankara: Milli Eğitim Bakanı

Miles, H., Huberman, A. M., \& Saldana, J. (2014). Qualitative data analysis a Methods Sourcebook. Arizona: Arizona State University.

Nichols, L. M. (1995). A comparison of two methods for teaching keyboarding in the elementary school. Computers in the Schools, 2(4). 
Nicolau, H., Montague, K., Guerreiro, T., Rodrigues, A., \& Hanson, V. L. (2017). Investigating laboratory and everyday typing performance of blind users. ACM Transactions on Accessible Computing (TACCESS), 10(1). doi:Artn 410.1145/3046785

Özcan, A. F., Canbulat, A. N. K., Baycan, D., Erdoğan, Ö., Bayat, S., Obalar, S., Yıldız, S., Çelenk, S., \& Erdoğan, T. (Eds.). (2013). Illkokuma yazma programı ve ögretimi. Ankara: Eğiten Kitap.

Perc, M. (2014). The Matthew effect in empirical data. Journal of The Royal Society Interface, 11(98). doi:10.1098/rsif.2014.0378

Pisha, B. G. (1994). Rates of development of keyboarding skills in elementary school-aged children with and without identified learning disabilities. (Doktora Tezi). Harvard University, Boston.

Preminger, F., Weiss, P. L. T., \& Weintraub, N. (2004). Predicting occupational performance: Handwriting versus keyboarding. American Journal of Occupational Therapy, 58(2), 193201.

Rao, K. (2006). Usability and impact of braille and audio output technologies for students with visual impairments or blindness. (Yüksek Lisans Tezi). State University of New York at Buffalo, New York.

Schmidt, R. A., Lee, T. D., Winstein, C., Wulf, G., \& Zelaznik, H. N. (2018). Motor control and learning: A behavioral emphasis. Washington: Human kinetics.

Smith, C. A. (1989). The effects of handwriting versus word processing on learning-disabled students' written composition. (Doktora Tezi). Columbia University Teachers College, Columbia

Stevenson, N. C., \& Just, C. (2014). In early education, why teach handwriting before keyboarding? Early Childhood Education Journal, 42(1), 49-56.

Subaşıŏglu, F. (2000). Engellilerin internet'e erişimi üzerine. Türk Kütüphaneciliği, 14(2), 188204.

Vener, A. R., \& Glinert, E. P. (1988). Magnex: a text editor for the visually impaired. ACM Sixteenth Annual Conference on Computer Science, Georgia.

Wagh, P., Prajapati, U., Shinde, M., Salunke, P., Chaskar, V., Telavane, S., \& Yadav, V. (2016). E-Braille-a self-learning Braille device. 22. National Conference on Communication (NCC), Guwahati.

Washburn, K. M. M. (2016). No literacy left behind: Addressing information illiteracy in the information age. Carolina: Western Carolina University.

Weigelt Marom, H., \& Weintraub, N. (2015). The effect of a touch-typing program on keyboarding skills of higher education students with and without learning disabilities. Research in developmental disabilities, 47, 208-217. doi:10.1016/j.ridd.2015.09.014

Yaşar, Ş., \& Aktay-Güvey, E. (2015). Okuma becerisi açısından cümle yöntemi ve ses temelli cümle yöntemi. Journal of Turkish Studies, 10(7).

Yıldırım, A., \& Şimşek, H. (2003). Sosyal bilimlerde nitel araştırma yöntemleri. Ankara: Seçkin Yayıncilık.

Zwicker, J. G., \& Harris, S. R. (2009). A reflection on motor learning theory in pediatric occupational therapy practice. Canadian Journal of Occupational Therapy, 76(1), 29-37. 